УДК 378.091:355.237.092.4](043.3)

DOI:

Юлія Медвідь, науковий співробітник науково-організаиійного відділу, Наиіональна академія Начіональної гвардії України

Еліна Ященко, старший помічник начальника відділення мовного тестування мовного відділу, Наџіональна академія Національної гвардії України Ілля Ященко, старший викладач відділення мовної підготовки мовного відділу, Національна академія Національної гвардії України

\title{
МЕТОДИКА ФОРМУВАННЯ ГОТОВНОСТІ МАЙБУТНІХ ОФІЦЕРІВ ЗАПАСУ ДО СЛУЖБОВО-БОЙОВОЇ ДІЯЛЬНОСТІ В ПРОЦЕСІ ПРОФЕСІЙНОЇ ПІДГОТОВКИ
}

У статті визначено методику формування готовності майбутніх офіиерів запасу до службово-бойової діяльності, яка охоплює взаємопов'язані форми організації навчальної та виховної діяльності, методи та засоби. Реалізачія методики в освітньому процесі забезпечується навчально-методичним супроводом розділами програми “Організація та методика роботи з особовим складом” та “Військово-технічна $і$ військово-спечіальна підготовка”.

Ключові слова: методика; готовність; офіцери запасу; службово-бойова діяльність; професійна підготовка; педагогічні умови.

Табл. 2. Лім. 15.

Yuliya Medvid, Researcher of the Scientific and Organizational Department, National Academy of the National Guard of Ukraine Elina Yashchenko, Senior Officer of the Language Testing of the Language Department National Academy of the National Guard of Ukraine Illia Yashchenko, Senior Lecturer of the Language Training of the Language Department, National Academy of the National Guard of Ukraine

\section{THE FORMATION METHODICS OF THE FUTURE RESERVE OFFICERS TO THE COMBAT SERVICE IN PROFESSIONAL TRAINING PROCESS}

The article describes the formation methodic of the readiness of the future reserve officers for combat service in the process of professional training, which is based on the organization of a holistic process that determines the functioning of the content training components. It covers interconnected forms of learning organization activity (lectures, practical and group tasks, seminars, consultations, self-preparation), forms of organization of educational activity (professional meetings, excursions), methods (interactive; informational-research; discussions; games, trainings, case methods, that simulate different aspects of professional activity; the use of educational videos; observation) and means (manuals, textbooks, didactic material, means of information and communication technologies, simulators). Implementation of the methodology in the educational process is ensured by educational and methodological support by chapters of the program "Organization and methodology of work with personnel" and "Military-technical and military-special training", an also facultative "Physical training".

To the chapter of the program "Organization and methodology of work with personnel" were added modules, by which military personnel of the National Guard of Ukraine passes annual training and training abroad in higher education institutions and specialized centers of NATO member states and partners in the framework of the NATOUkraine Professional Development Program. The main purpose of the programs offered by the Alliance's international experts is to provide Ukrainian military personnel with an information base to develop and develop practical skills for their implementation in the performance of their functional responsibilities, including: "Officers public speeches", "Formation of conditions for gender equality in military units", "Strategic communications", "Tactical medicine" and "Leadership". To the chapter of the program "Military-technical and military-special training" were added lecture about the principles and processes on which based the work of modern systems and mechanisms, that assure work of the military equipment, training on APS-4E, anti-tank and anti-aircraft complexes simulators, as well as in multimedia shooting range.

Keywords: methodic; readiness; a reserve officer; military and combat activity; professional training; organizational and pedagogical conditions.

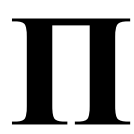
остановка проблеми. Сучасні потреби Збройних Сил України та інших військових формувань в особовому складі, задекларований перехід на стандарти передових країн Європи, необхідність підвищення мотивації до проходження військової служби у суспільстві вимагають удосконалення існуючої системи комплектування військових 


\section{МЕТОДИКА ФОРМУВАННЯ ГОТОВНОСТІ МАЙБУТНІХ ОФІЦЕРІВ ЗАПАСУ ДО СЛУЖБОВО-БОЙОВӦ̈ ДІЯЛЬНОСТІ В ПРОЦЕСІ ПРОФЕСІЙНОЇ ПІДГОТОВКИ}

формувань. Головною причиною виникнення проблеми формування, розвитку і використання людських ресурсів військового резерву військових формувань $є$ негативні демографічні процеси, які характеризуються зменшенням загальної чисельності населення держави. На динаміку значень цих показників впливають погіршення стану здоров'я населення, зниження народжуваності та зовнішня міграція. Втрати людських ресурсів за результатами антитерористичної операції, операції об'єднаних сил (АТО, ООС) на сході України спонукають до змін у системі військової освіти, особливо це стосується процесу професійної підготовки громадян України за програмою підготовки офіцерів запасу. Події останніх років свідчать про наявність принципових розбіжностей між потребами та традиційним змістом і методами підготовки військового резерву для військових формувань. Існуючі підходи до організації освітнього процесу майбутніх офіцерів запасу виявилися недостатньо ефективними. Унаслідок цього за наявності достатнього за чисельністю резерву у державі відчувається дефіцит кваліфікованих кадрів 3 числа офіцерів запасу. Серед здобувачів, які навчаються за програмою підготовки офіцерів запасу, дві п'ятих не готові займатися надалі службово-бойовою діяльністю (СБД).

Аналіз останніх досліджень і публікацій. Формуванню та розвитку готовності майбутніх офіцерів до СБД, зокрема до управління своїми підрозділами посвячені немало праць. Їх можна розділи за етапами професійного становлення військовослужбовця [3, 316]: професійного самовизначення щодо проходження військової служби [4], адаптації до службово-бойової та освітньої діяльностей [9], формуванні та удосконалювання необхідних компетентностей для організації СБД [5]. Проблемою вдосконалення професійної підготовки громадян України за програмою підготовки офіцерів запасу займаються наразі такі вчені, як В.В. Баришніков, О.О. Безносюк, А.В. Волошенко, А.Й. Дерев'янчук, О.В. Діденко, Я.Б. Зорій, В.І. Макеєв, О.М. Маслій, Т.М. Мацевко, В.М. Монастирський, С.М. Морозов, О.К. Неймирок, А.Ф. Раскошний, В.М. Романчук, О.В. Сенюк, С.В. Сінкевич [10], В.П. Чабаненко, A.I. Яворський та ін. Однак, попри значний інтерес учених до досліджуваного феномена, у наукових дослідженнях не враховані зміна способу комплектування військових формувань 3 призовного на контрактний, а також досвід бойових дій на сході України; потребують перегляду педагогічні умови формування готовності майбутніх офіцерів запасу до СБД в процесі професійної підготовки та їх вплив на особистість. В минулих наших публікаціях виявлено, теоретично обгрунтовано дієвість педагогічних умов формування готовності майбутніх офіцерів запасу до СБД, зокрема: активізування психологічної (насамперед пов'язаної 3 організацією роботи з підлеглим особовим складом), вогневої та фізичної підготовки офіцерів запасу; посилення практичної спрямованості підготовки офіцерів запасу (шляхом проведення занять на тренажерах військової техніки, на території військової частини); залучення офіцерів - учасників АТО (ООС) до підготовки здобувачів, які навчаються за програмою підготовки офіцерів запасу [6]; а також розроблено циклічний механізм реалізації педагогічних умов формування готовності майбутніх офіцерів запасу до СБД, який ураховує залежність функціонування компонентів змістової підготовки від наявності необхідних ресурсів, стан яких може змінюватись у часі [7].

Мета статті - визначити методику формування готовності майбутніх офіцерів запасу до СБД в процесі професійної підготовки.

Виклад основного матеріалу. У "Великому тлумачному словнику сучасної української мови” поняття “методика" розглядається як “сукупність взаємопов’ язаних способів та прийомів доцільного проведення будь-якої роботи" [1,552]. Багатоаспектне трактування цього поняття подано в "Українському педагогічному словнику". Термін "методика" у ньому визначено як “галузь педагогічної науки, яка досліджує закономірності навчання", а тому може розглядатися як часткова дидактика, зміст якої складається з мети, завдань, “вироблення відповідно до завдань і змісту навчання методів, методичних засобів і організаційних форм навчання" [2, 206]. Окреслений підхід і був покладений нами за основу розробленої методики формування готовності майбутніх офіцерів запасу до СБД в процесі професійної підготовки.

Зауважимо, що методика формування готовності майбутніх офіцерів запасу до СБД в процесі професійної підготовки передбачає вдосконалення змісту програми, навчального плану, комплексів навчально-методичного забезпечення, що є основою для організації, управління освітньою діяльністю майбутніх фахівців.

Для реалізації визначених педагогічних умов використано можливість, що зазначена в Інструкції про організацію військової підготовки громадян України за програмою підготовки офіцерів запасу [8], - здійснено перерозподіл навчального часу між розділами програми підготовки, а саме: на 


\section{МЕТОДИКА ФОРМУВАННЯ ГОТОВНОСТІ МАЙБУТНІХ ОФІЦЕРІВ ЗАПАСУ ДОСЛУЖБОВО-БОЙОВОЇ ДІЯЛЬНОСТІ В ПРОЦЕСІ ПРОФЕСІЙНОЇ ПДГОТОВКИ}

Таблиця 1.

Розподіл часу між розділами програми військової підготовки

\begin{tabular}{|c|c|c|}
\hline \multirow[t]{2}{*}{ Розділ програми військової підготовки } & \multicolumn{2}{|c|}{ Обсяг часу на розділ програми у кредитах СКТС } \\
\hline & $\begin{array}{c}\text { до впровадження } \\
\text { педагогічних умов }\end{array}$ & $\begin{array}{c}\text { після впровадження } \\
\text { педагогічних умов }\end{array}$ \\
\hline Загальновійськова підготовка & 8 & 5 \\
\hline Організація та методика роботи 3 особовим складом & 3 & 5 \\
\hline Тактична і тактико-спеціальна підготовка & 8 & 8 \\
\hline Військово-технічна і військово-спеціальна підготовка & 10 & 11 \\
\hline
\end{tabular}

розділ “Організація та методика роботи 3 особовим складом” відведено 5 кредитів СКТС, на розділ "Військово-технічна і військовоспеціальна підготовка" - 11 кредитів СКТС (табл. 1). Внесено відповідні зміни до навчальнометодичного забезпечення підготовки майбутніх офіцерів запасу.

Перша педагогічна умова - активізування психологічної (насамперед пов'язаної 3 організацією роботи 3 підлеглим особовим складом), вогневої та фізичної підготовки офіцерів запасу.

До навчально-методичного забезпечення підготовки майбутніх офіцерів запасу внесено відповідні зміни (табл. 2). Вони грунтувалися на основі запитів та практичних потреб здобувачів, що відповідатиме не лише їхнім особистим, а й державним інтересам.

До розділу програми “Організація та методика роботи з особовим складом” були додані змістові модулі, за якими військовослужбовці Національної гвардії України щороку проходять навчання та підвищення кваліфікації за кордоном у закладах вищої освіти та спеціалізованих центрах державчленів та партнерів НАТО в рамках Програми Професійного Розвитку Україна-НАТО. Головна мета програм, які пропонують міжнародні фахівці Альянсу - надати українським військовослужбовцям інформаційну базу сформувати і розвити практичні навички для їх реалізації під час виконання функціональних обов'язків. Серед них: “Публічні виступи офіцера", “Формування умов забезпечення гендерної рівності у військових частинах”, “Стратегічні комунікації”, “Тактична медицина" та “Лідерство”. До розділу програми "Військово-технічна і військово-спеціальна підготовка" була додана лекція з принципів дій і процесів, на яких грунтується робота сучасних систем, механізмів, що забезпечують роботу військової техніки, відпрацювання завдань на тренажерах БТР-4Е, ПТРК та ПЗРК, а також у мультимедійному тирі.

Таблиця 2.

Зміни у навчально-методичному забезпеченні підготовки майбутніх офіцерів запасу

\begin{tabular}{|c|c|c|c|c|c|}
\hline \multirow[t]{2}{*}{ Назви розділів, занять та навчальних питань } & \multirow[t]{2}{*}{ Усього } & \multicolumn{4}{|c|}{ У тому числі } \\
\hline & & л. & П. 3. & Г. 3. & c. p. \\
\hline \multicolumn{6}{|c|}{ Розділ “Організація та методика роботи з особовим складом” } \\
\hline 3М “Публічні виступи офіцера” & 12 & 2 & & 4 & 6 \\
\hline $\begin{array}{l}\text { ЗМ “Формування умов забезпечення } \\
\text { підрозділах військових фордерної рівності } \\
\text { у }\end{array}$ & 12 & 2 & 2 & 2 & 6 \\
\hline 3М “Стратегічні комунікації” & 12 & 2 & & 4 & 6 \\
\hline 3М “Тактична медицина” & 12 & 2 & & 4 & 6 \\
\hline ЗМ “Лідерство” & 12 & 2 & & 4 & 6 \\
\hline Усього & 60 & 10 & 2 & 18 & 30 \\
\hline \multicolumn{6}{|c|}{ Розділ “Військово-технічна і військово-спеціальна підготовка" } \\
\hline $\begin{array}{l}\text { Принципи дій і процесів, на яких грунтується робота сучасних } \\
\text { систем, механізмів, що забезпечують роботу військової техніки }\end{array}$ & 2 & 2 & & & \\
\hline Відпрацювання завдань на тренажері БТР-4Е & 10 & & 4 & 2 & 4 \\
\hline Відпрацювання завдань на тренажері ПТРК & 6 & & 4 & & 2 \\
\hline Відпрацювання завдань на тренажері ПЗРК & 6 & & 4 & & 2 \\
\hline Відпрацювання завдань у мультимедійному тирі & 6 & & & & 6 \\
\hline Усього & 30 & 2 & 12 & 2 & 14 \\
\hline
\end{tabular}




\section{МЕТОДИКА ФОРМУВАННЯ ГОТОВНОСТІ МАЙБУТНІХ ОФІЦЕРІВ ЗАПАСУ ДОСЛУЖБОВО-БОЙОВОЇ ДІЯЛЬНОСТІ В ПРОЦЕСІ ПРОФЕСІЙНОӤ ПДГОТОВКИ}

Змістовий модуль "Публічні виступи офіцера" $\epsilon$ необхідною складовою частиною гуманітарної підготовки майбутнього офіцера: військова професія, незалежно від спеціалізації, тісно пов'язана з умінням говорити, організовувати, виховувати. На лекції розглядалися етапи підготовки виступу, техніка ефективного початку виступу та алгоритму подолання стресу перед аудиторією. До лекції були додані групові заняття, які допомагали майбутнім офіцерам опанувати матеріал із практичної риторики. Здобувачі складали різні види планів і тез виступу, логічно розставляли наголоси у реченнях, писали невеликі промови за пропонованою темою, розмежовували поняття індукції та дедукції та визначали типи логічних помилок, типи промов і специфічні особливості різних видів публічних виступів. Під час проведення групових занять навчальні групи розподіляли на підгрупи, кожна з яких отримувала своє завдання. Після обговорення кожна підгрупа захищала своє рішення.

Змістовий модуль “Формування умов забезпечення гендерної рівності у військових частинах". Цей змістовий модуль $є$ необхідною складовою частиною гуманітарної підготовки майбутнього офіцера, спрямований на формування навичок недискримінаційної поведінки, протидії гендерно зумовленому насильству, які $є$ важливим й ефективним сучасним інструментом реформування сектору безпеки та оборони України. У цьому змістовому модулі була використана проблемна лекція. Науково-педагогічними працівниками перед здобувачами було висвітлено проблеми, пов'язані 3 гендерною нерівністю, гендерним дисбалансом як в Україні в цілому, так у підрозділах військових частин зокрема, які вони не в змозі подолати за допомогою наявних знань. Викладачі спонукали здобувачів до самостійного пошуку можливих способів вирішення поставлених проблем, активізували їхн навчально-пізнавальну діяльність, залучали їх до обговорення. Під час такої лекції здобувачі набували знання через дію, активне мислення, спільну роботу над розв'язанням поставлених проблем. Під час практичних і групових занять розглядалися поняття гендерної рівності й інтегрування принципу рівних прав та можливостей жінок i чоловіків у реформи в Україні. Кожен виступ здобувача підтримувався активним обговоренням.

Змістовий модуль “Стратегічні комунікації”. Мета змістового модуля - ознайомити зі змістом та особливостями стратегічних комунікацій, сформувати розуміння поведінки військовослужбовців в інформаційному полі та навчити протидії незаконній пропаганді військових конфліктів. У наведеному змістовому модулі було використано лекцію-провокацію із заздалегідь запланованими у іiї змісті певними неточностями та помилками, які здобувачі повинні були виявити під час заняття й оголосити наприкінці лекції. Це утримувало увагу здобувачів протягом усієї лекції, значно підвищило їх інтерес до заняття. Під час групових занять майбутні офіцери навчилися формувати рекламу проходження військової служби, виявляти фейки та спростовувати їх.

Змістовий модуль “Тактична медицина”. Перша медична допомога пораненим на полі бою полягає у виборі найоптимальнішої комбінації належної медичної практики та адекватної тактики невеликих військових підрозділів. Специфіка надання медичної допомоги залежить від тактичної ситуації на полі бою, характеру отриманих поранень, рівня знань та навичок медпрацівника, який перший контактує 3 пораненим, та наявного медичного обладнання. На відміну від відділення невідкладної допомоги в лікарні, мета роботи якого полягає в лікуванні хворого, допомога пораненим на полі бою є лише частиною завдання військового підрозділу, відповідно, мобільним підрозділам може бути важко поєднати продовження бойових дій та догляд за пораненими і водночас забезпечити ефективність виконання завдань. Під час проведення групових занять із здобувачами на території військової частини були розглянуті такі питання: загальні поняття тактичної медицини; самодопомога та допомога пораненим у військово-польових умовах; зупинення кровотечі; методика надання домедичної допомоги в секторі обстрілу; евакуація пораненого в сектор укриття; тактика евакуації пораненого у складі групи. Здобувачі зрозуміли, що набуті знання з основ тактичної медицини є корисними не лише майбутнім офіцерам, а й волонтерам, іншим громадянам, які опинилися у районі ведення бойових дій і зможуть своєчасно надати допомогу собі й оточуючим, використовуючи тактику дій.

Змістовий модуль “Лідерство”. Цей змістовий модуль є необхідною складовою частиною гуманітарної підготовки майбутнього офіцера, спрямований на психологічне забезпечення розвитку лідерських якостей майбутніх офіцерів. У змістовому модулі “Лідерство” була використана лекція-брейнстормінг (“мозкова атака”), яка передбачає генерацію великої кількості ідей з подальшою їх селекцією. Ефективність засвоєння інформації, здобутої таким шляхом, значно вища, ніж у тому випадку, коли іiі подає сам науково-педагогічний працівник, 


\section{МЕТОДИКА ФОРМУВАННЯ ГОТОВНОСТІ МАЙБУТНІХ ОФІЦЕРІВ ЗАПАСУ ДОСЛУЖБОВО-БОЙОВОЇ ДІЯЛЬНОСТІ В ПРОЦЕСІПРОФЕСІЙНОӤ ПІДГОТОВКИ}

а здобуті таким чином знання не тільки ефективно засвоюються, а й тривалий час зберігаються у пам'яті. Викладачі також провели групові заняття, на яких здобувачі в ролі лідерів навчалися приймати рішення на основі змодельованих ситуацій, розглянутих на попередніх заняттях інших змістових модулів розділу програми “Організація та методика роботи з особовим складом”. Здобувачі активно працювали над практичними завданнями у мікроколективах.

Розкриваючи навчальний матеріал 3 тем i питань розділу програми “Організація та методика роботи з особовим складом” загалом, науковопедагогічні працівники активізовували роботу здобувачів, залучаючи їх до обговорення проблем, обміну думками, що сприяло кращому засвоєнню навчального матеріалу та розумінню ними СБД. Для підвищення мотивації здобувачів освіти заохочувалася науково-пошукова робота здобувачів, що було враховано під час оцінювання. Пізнавальна активність здобувачів зростала під час вирішення кейсів, використання інформаційнокомунікаційних технологій. Предметом обговорення групових занять була певна професійна ситуація на основі реальних випадків СБД.

На вогневу підготовку додатково було виділено 6 годин для самостійної роботи. Здобувачі були забезпечені можливістю для відпрацьовування прийомів і правил стрільби в інтерактивному мультимедійному лазерному тирі у зручний для них час, вільний від проведення планових занять іншими здобувачами. Такий тир дає можливість застосовувати сучасні інтерактивні технології у підготовці здобувачів зі стрілецької зброї без використання бойових комплектів (набоїв). Здобувачі обов'язково проходили інструктаж 3 техніки безпеки під час роботи з лазерними пристроями та правил поведінки у приміщеннях iз підвищеною небезпекою. Науковопедагогічними працівниками було відмічено досягнення позитивних результатів стрільби всіма здобувачами.

На жаль, Інструкція про організацію військової підготовки громадян України за програмою підготовки офіцерів запасу [8] не дає можливості реалізувати виділення додаткового часу на фізичну підготовку. У своїх дослідженнях 3 проблем навчання майбутніх офіцерів запасу серед основних методичних засад зазначеного процесу С.В. Сінкевич пропонує організовувати додаткові заняття із студентами, які мають прогалини у знаннях, у формі факультативних занять [10, 275]. У закладах вищої освіти є гуртки 3 фізичної підготовки. Здобувачам експериментальної групи була надана можливість їх відвідувати факультативно. На початку експерименту у такій можливості зацікавлення проявляли близько четвертої частини осіб, а після його завершення відвідування гуртків зменшилося до $10 \%$.

Друга педагогічна умова - посилення практичної спрямованості підготовки офіцерів запасу (шляхом проведення занять на тренажерах військової техніки, на території військової частини).

Для реалізації цієї педагогічної умови до розділу програми "Військово-технічна і військовоспеціальна підготовка” була додана лекція, що розкриває принципи дій і процесів, на яких грунтується робота сучасних систем, механізмів, що забезпечують роботу військової техніки, а також практичні та групові заняття на тренажерах БТР-4Е, ПТРК та ПЗРК. Лекція за темою "Принципи дій і процесів, на яких грунтується робота сучасних систем, механізмів, що забезпечують роботу військової техніки" була проведена як лекція-візуалізація, спрямована на поліпшення сприйняття навчального матеріалу за рахунок використання образного мислення, підключення зорової пам'яті. Під час іiї проведення науково-педагогічні працівники кафедр використовували мультимедійне обладнання, інтерактивні дошки, роздатковий матеріал зі схемами, рисунками, діаграмами. Це дозволило не лише сприймати інформацію на слух, а ще й залучати зорове сприйняття, у результаті чого здобувачі засвоїли більший обсяг лекційного матеріалу. Роль викладачів зводиться до коментування інформації, поданої з використанням технічних засобів навчання. Організація практичного заняття повинна принципово відрізнятися від заняття теоретичного виду: на такому занятті необхідно створити умови для виконання завдань кожним здобувачем. Тому на перший план виходить конструювання занять. Під час конструювання кожного практичного заняття науково-педагогічні працівники визначили: мету проведення занять; місце проведення заняття; зміст підготовки до практичних занять викладача, його помічників, здобувачів; матеріальне забезпечення занять; документацію (плани, завдання, методичні вказівки тощо), яку необхідно підготувати, а також терміни її видачі помічникам керівника занять і здобувачам; послідовність проведення вступної, основної і заключної частин заняття та їх зміст; найбільш ефективні форми і методи навчання, що доцільно використовувати для досягнення навчально-виховних цілей практичних занять; навчальні питання, на які треба 


\section{МЕТОДИКА ФОРМУВАННЯ ГОТОВНОСТІ МАЙБУТНІХ ОФІЦЕРІВ ЗАПАСУ ДОСЛУЖБОВО-БОЙОВОЇ ДІЯЛЬНОСТІ В ПРОЦЕСІ ПРОФЕСІЙНОӤ ПДГОТОВКИ}

звернути увагу під час виконання здобувачами практичних завдань; порядок використання технічних засобів навчання, військової техніки, навчально-тренувальних засобів та іншого матеріального забезпечення занять; заходи безпеки й охорони довкілля.

Динамічний тренажер екіпажу БТР-4Е призначений для вивчення особовим складом матеріальної частини основних елементів системи управління вогнем, елементів керування бойовою машиною, для забезпечення індивідуального навчання командирів, навідників та водіїв БТР-4Е, а також проведення спільної роботи у складі екіпажу 3 метою набуття i закріплення екіпажем практичних навичок під час роботи з комплексом управління вогнем, водіння, відпрацювання взаємодії членів екіпажу під час заряджання (розряджання) озброєння БТР-4Е, ведення бойових дій у різних умовах, удень і вночі, 3 наземними і повітряними цілями. Навчальнодіючий стенд бойового модуля БМ-7 "Парус" БТР-4Е призначений для забезпечення індивідуального навчання командирів, навідників БТР-4Е, а також проведення спільної роботи у складі екіпажу з метою набуття і закріплення ним практичних навичок під час здійснення: контрольного огляду озброєння; монтажу і демонтажу озброєння бойового модуля БМ-7; завантаження боєприпасів; заряджання i розряджання озброєння; заміни магазинів кулемета та гранатомета; усунення затримок під час дій з озброєнням бойового модуля. Навчання на тренажерах проводилося 3 метою вдосконалення навичок у діях 3 озброєнням бойового модуля БТР-4Е і доведення їх виконання до автоматизму. Тренування на тренажерах повторювалися доти, поки здобувачі не засвоїли виконання без помилок операцій (прийомів, дій) 3 практичного виконання вогневих завдань. Використання цих тренажерів у навчанні здобувачів привело до підвищення якості їх підготовки як екіпажів БТР-4Е та застосування ПТРК та ПЗРК.

За результатами аналізу навчальнометодичного забезпечення крім занять змістового модуля "Тактична медицина" були визначені інші практичні та групові заняття, які проводилися на території військової частини. Посилення практичної спрямованості підготовки офіцерів запасу (шляхом проведення занять на тренажерах військової техніки, на території військової частини) найбільше вплинуло на ступінь оволодіння знаннями за програмою підготовки офіцерів запасу, на вміння використовувати набуті знання у СБД.
Третя педагогічна умова - залучення офіцерів - учасників АТО (ООС) до підготовки здобувачів, які навчаються за програмою підготовки офіцерів запасу.

Цю педагогічну умову легше реалізувати у вищих військових навчальних закладах, оскільки серед їх працівників $є$ особи, які відповідають зазначеній педагогічній умові. Завідувачів кафедр як вищих військових навчальних закладів, так і військових навчальних підрозділів закладів вищої освіти необхідно заздалегідь ознайомлювати 3 розкладом занять та навчально-методичним забезпеченням розділів програми осіб, які готові у парі з викладачем провести такі заняття. Перевагами цих занять $є$ передавання досвіду управління підрозділом в умовах ведення бойових дій не тільки здобувачам, а й викладачеві. Офіцер - учасник АТО (OOC) може й самостійно провести таке заняття. Проте необхідно враховувати його недостатній рівень методичної підготовки. Науково-педагогічні працівники заздалегідь зустрічалися 3 офіцерами учасниками АТО (OOC) та обговорювали план проведення заняття, місце і роль кожного 3 учасників. Поради бувальця активізовували роботу здобувачів, сприяли кращому засвоєнню навчального матеріалу та розумінню ними СБД. Особливо стимулюють здобувачів підтвердження бувальцем значення отримуваних ними знань здобувачами. Наприклад: “Студент Петренко, чому Ви не можете відповісти на запитання? Ви ж цей матеріал вивчали місяць тому. Уявіть собі, що Ви на полі бою. Перед Вами ворог. А Ви 3 гаслом: "Не стріляй у мій підрозділ, я пропустив це заняття і не знаю, що мені робити”. Після подібних ситуацій почуття відповідальності здобувачів загострювалося, ставлення до навчання у них змінювалося на краще. Залучення офіцерів - учасників АТО (ООС) до підготовки здобувачів, які навчаються за програмою підготовки офіцерів запасу, більш за все вплинуло на усвідомлення потреби у здійсненні СБД, на ціннісне ставлення до СБД, на ступінь оволодіння знаннями за програмою підготовки офіцерів запасу, на вміння використовувати набуті знання у СБД.

Висновки 3 даного дослідження i перспективи подальших розвідок. В статті визначено методику формування готовності майбутніх офіцерів запасу до СБД в процесі професійної підготовки, в основу якої покладено організацію цілісного процесу, що обумовлює функціонування компонентів змістової підготовки. Вона охоплює взаємопов'язані форми організації навчальної діяльності (лекції, практичні, групові, 


\section{МЕТОДИКА ФОРМУВАННЯ ГОТОВНОСТІ МАЙБУТНІХ ОФЩЦРРВ ЗАПАСУ ДОСЛУЖБОВО-БОЙОВОЇ ДІЯЛЬНОСТІ В ПРОЦЕСІ ПРОФЕСІЙНОЇ ПІДГОТОВКИ}

семінарські заняття, консультації, самостійну роботу), форми організації виховної діяльності (професіографічні зустрічі, екскурсіі), методи (інтерактивні; інформаційно-пошукові; дискусії; ігри, тренінги, кейс-метод, які моделюють різні аспекти професійної діяльності; використання навчальних фільмів; спостереження) та засоби (підручники, посібники, дидактичний матеріал, засоби інформаційно-комунікаційних технологій, тренажери). Реалізація методики в освітньому процесі забезпечується навчально-методичним супроводом розділами програми “Організація та методика роботи з особовим складом” та "Військово-технічна і військово-спеціальна підготовка”, а також факультативу “Фізична підготовка".

Перспективними напрямами подальших наукових розвідок $є$ підвищення кваліфікації науково-педагогічних працівників кафедр військової підготовки відповідно до запропонованої методики формування готовності майбутніх офіцерів запасу до СБД.

\section{ЛІТЕРАТУРА}

1. Великий тлумачний словник сучасної української мови (з дод. і допов.) / уклад. і голов. ред. В. Т. Бусел. Київ; Ірпінь. 2007. 1736 с.

2. Гончаренко С. У. Український педагогічний словник / гол. ред. С. Головко. Київ, 1997. 376 с.

3. Медвідь М. М. Методологія формування i розвитку людських ресурсів для використання у службово-бойовій діяльності: дис. д-ра економ. наук. Харків, 2015. 577 с.

4. Медвідь М. М., Бабічев А. В., Дем'янишин В. М., Медвідь Ю. І., Бухун А. Г. Попереду змін у військових системах вищої освіти та професійної орієнтації. Вісник Черкаського університету. Серія : Педагогічні науки. 2016. № 14. C. 76-87.

5. МедвідьМ.М.,Павлов Я.В.,МедвідьЮ. І., ТробюкН. Ю., Дем'янишин В. М., Александрова О. А. Шляхи формування та розвитку готовності офіцерів до управління їх підрозділами в умовах сумісного виконання завдань з підрозділами країн-партнерів України. Вісник Черкаського університету. Серія : Педагогічні науки. 2018. № 14. С. 45-52.

6. Медвідь Ю. І., Водчиць О. Г., Медвідь М. М. Результати дослідження стану готовності майбутніх офіцерів запасу до службово-бойової діяльності. Вісник Глухівського національного педагогічного університету імені Олександра Довженка. Глухів: Глухівськ. НПУ ім. О. Довженка, 2018. Вип. 1 (36). С. 184-192.

7. Медвідь Ю. І., Бородін Б. Д., Самсоненко А. І., Мокреєв В. І. Реалізація організаційно-педагогічних умов формування готовності майбутніх офіцерів запасу до службово-бойової діяльності. Інновачійна педагогіка. 2019. Вип. 9. Т. 2. С. 61-68.

8. Про затвердження Інструкції про організацію військової підготовки громадян України за програмою підготовки офіцерів запасу: наказ Міноборони України, МОН України від 14.12.2015 p. № 719/1289. URL: http:// zakon4.rada.gov.ua/laws/show/z1678-15/page (дата звернення: 15.04.2019).

9. Сергиенко Т. Н., Медвидь М. М., Рютин В. В. Модель социальнопедагогической профилактики дезадаптации курсантов младших курсов высших военных учебных заведений и анализ результатов эксперимента по ее внедрению. Wschonioeuropejskie Czasopismo Naukowe. 2018. № 3 (31), 5. C. 29-39.

10. Сінкевич С. В. Методичні засади індивідуалізації навчання майбутніх офіцерів запасу. Збірник наукових праць Національної академї Державної прикордонної служби України. Педагогічні та психологічні науки. 2013. № 1. С. 269-276.

\section{REFERENCES}

1. Velykyi tlumachnyi slovnyk suchasnoi ukrainskoi movy [A great explanatory dictionary of modern Ukrainian]. (Ed.).V. T. Busel. Kyiv; Irpin. 2007. 1736 p. [in Ukrainian].

2. Honcharenko, S. U. (1997). Ukrainskyi pedahohichnyi slovnyk [Ukrainian Pedagogical Dictionary]. (Ed.).S. Holovko. Kyiv, 376 p. [in Ukrainian].

3. Medvid, M. M. (2015). Metodolohiia formuvannia i rozvytku liudskykh resursiv dlia vykorystannia u sluzhbovo-boiovii diialnosti [Methodology of formation and development of human resources for use in servicecombat activity]. Doctor's thesis. Kharkiv, 577 p. [in Ukrainian].

4. Medvid, M. M., Babichev, A. V., Demianyshyn, V. M., Medvid, Yu. I. \& Bukhun, A. H. (2016). Poperedu zmin u viiskovykh systemakh vyshchoi osvity ta profesiinoi oriientatsii [Ahead of changes in military systems of higher education and professional orientation]. Bulletin of the Cherkasy University. Serial Pedagogical sciences. No. 14. pp. 76-87. [in Ukrainian].

5.Medvid,M.M.,Pavlov, Ya. V.,Medvid,Yu. I., Trobiuk,N. Yu., DemSianyshyn, V. M. \& Aleksandrova, O. A. (2018). Shliakhy formuvannia ta rozvytku hotovnosti ofitseriv do upravlinnia yikh pidrozdilamy $\mathrm{v}$ umovakh sumisnoho vykonannia zavdan z pidrozdilamy krain-partneriv Ukrainy[Ways of formation and development of officers' readiness to manage their units in conditions for joint implementation of tasks with the units of partner countries of Ukraine]. Bulletin of Cherkasy University. Series: Pedagogical Sciences. No. 14. pp. 45-52. [in Ukrainian].

6. Medvid, Yu. I., Vodchyts, O. H. \& Medvid, M. M. (2018). Rezultaty doslidzhennia stanu hotovnosti maibutnikh ofitseriv zapasu do sluzhbovo-boiovoi diialnosti [The results of the research of the readiness of future reserve officers to military service]. Bulletin of Glukhiv National Pedagogical University. Glukhiv: Glukhivsk. Vol. 1 (36). pp. 184-192. [in Ukrainian].

7. Medvid, Yu. I., Borodin, B. D., Samsonenko, A. I. \& Mokreiev, V. I. (2019). Realizatsiia orhanizatsiinopedahohichnykh umov formuvannia hotovnosti maibutnikh ofitseriv zapasu do sluzhbovo-boiovoi diialnosti [Realization of organizational and pedagogical 
conditions of formation of readiness of future reserve officers for military service]. Innovative pedagogy. issue. 9. Vol. 2. pp. 61-68. [in Ukrainian].

8. Pro zatverdzhennia Instruktsii pro orhanizatsiiu viiskovoi pidhotovky hromadian Ukrainy za prohramoiu pidhotovky ofitseriv zapasu: nakaz Minoborony Ukrainy, MON Ukrainy vid 14.12.2015 r. № 719/1289 [Approval of the Instruction on the Organization of Military Training of Ukrainian Citizens under the Reserve Officers Training Program: Minister of Defense order, Ministry of Defense of Ukraine, 14.12.2015. № 719/1289]. Available at: http:// zakon4.rada.gov.ua/laws/show/z1678-15/page (accessed 15 Apr.2019). [in Ukrainian].

9. Sergienko, T. N., Medvid, M. M. \& Ryutin, V. V. (2018). Model sotsialnopedagogicheskoy profilaktiki dezadaptatsii kursantov mladshikh kursov vysshikh voennykh uchebnykh zavedeniy i analiz rezultatov eksperimenta po ee vnedreniyu [Model of sociopedagogical prevention of maladaptation of younger cadets of higher military educational institutions and analysis of the results of the experiment on its introduction]. Wschonioeuropejskie Czasopismo Naukowe. No.3 (31), 5. pp. 29-39.[in Russian].

10. Sinkevych, S. V. (2013). Metodychni zasady indyvidualizatsii navchannia maibutnikh ofitseriv zapasu [Methodical principles of individualization of training of future reserve officers]. Collection of scientific works of the National Academy of State Border Guard Service of Ukraine. Pedagogical and psychological sciences. No. 1. pp. 269-276. [in Ukrainian].

Стаття надійшла до редакції 10.10.2019

УДК: $791: 398$ (477) “20”

DOI:

Катерина Степаненко, асистент кафедри тележурналістики та майстерності актора Київського начіонального університету культури і мистеитв

\section{ВІДРОДЖЕННЯ ФОЛЬКЛОРНОЇ СТИЛІСТИКИ В УКРАЇНСЬКОМУ КІНО 2000-Х РОКІВ}

У статті розглянуто проиес відродження фольклорної стилістки у вітчизняному кінематографi, який відбувся на початку 2000-х років. Доведено, щзо проаналізовані художні фільми (в тому числі, короткометражні кінокартини та документалістика) набули таких важливих елементів кінопоетики, як автентичний спів, народні танці, фольклорна музика, використання різноманітних діалектів украӥнської мови, натуралістичність зйомок, живописний візуальний ряд тощьо.

Ключові слова: поетичне кіно; фольклорна стилістка; украӥнський кінематограф.

Jim. 15.

Kateryna Stepanenko, Assistant Professor of the Television Journalism and Acting Department Kyiv National University of Culture and Arts

\section{REVIVAL OF FOLKLORE STYLISTICS IN THE UKRAINIAN MOVIE IN 2000-S}

The article deals with the process of revival of folklore stylist in domestic cinema, which took place in the early 2000s. The paper points out that during the 1960s and 1970s Ukrainian moviegoers suffered almost the greatest number in the second half of the twentieth century harassment by official Soviet power. Most films of the notorious poetic direction, started by director S. Paradzhanov and continued by his colleagues and associates $-L$. Osika, V. Denysenko, Y. Illenko, M. Maschenko, I. Mykolaychuk and other artists, were banned; much of the interesting ideas were not realized.

With the beginning of the 1990s and the gaining of independence by Ukraine, the situation began to change gradually: the focus of attention of domestic writers and directors was the history of Ukraine, in particular the pages of its previously forbidden chronicle; a new original reading of Ukrainian literary classics appeared, involving many ethnographic components in the film process; there was a revival of the mystical and folklore trend in cinema.

Initiated in the 1990s, the processes intensified in the early 2000s and continue to strengthen in our time. In particular, a number of feature films have been released into Ukrainian cinema, in which the naturalistic nature of the shoots, the picturesque visual series, the attraction of authentic music, folk dances, the use of various dialects of the Ukrainian language, the reliance on literary classics and other stylistic features, have directed them to poetic folk. Philosophical understanding of the surrounding world, rooted in the sources of folk wisdom, was observed in short films and national documentary, which continued the development of stylistics of Ukrainian folk film school in the mid-twentieth century.

Keywords: poetic cinema; folklore stylist; Ukrainian cinematography.

П остановка проблеми. 3 історії вітчизняного кінематографа відомо, що продовж 1960 - 1970-х років українські кіномитці зазнали чи не найбільших у другій половині XX століття утисків з боку офіційної влади. Більшість фільмів славнозвісного поетичного напряму, започаткованого режисером С. Параджановим і продовженого його колегами 